\title{
A Mismatch between External Debt Finances and Consumption Cost in Nigeria
}

\author{
Cordelia Onyinyechi Omodero ${ }^{1, * \mathbb{D}}$, Ben-Caleb Egbide ${ }^{2}$, Joseph Ugochukwu Madugba ${ }^{2}$ and \\ Benjamin Ighodalo Ehikioya ${ }^{3}$ (I) \\ 1 Department of Accounting, College of Business and Social Sciences, Covenant University Ota, \\ Ota 110001, Nigeria \\ 2 Department of Accounting and Finance, College of Business and Social Sciences, Landmark University, \\ Omu-Aran 240001, Nigeria; ben-caleb.egbide@lmu.edu.ng (B.-C.E.); madugba.joseph@lmu.edu.ng (J.U.M.) \\ 3 Department of Banking and Finance, College of Business and Social Sciences, Covenant University Ota, \\ Ota 110001, Nigeria; benjamin.ehikioya@covenantuniversity.edu.ng \\ * Correspondence: cordeliaomodero@yahoo.com; or onyinyechi.omodero@covenantuniversity.edu.ng
}

Received: 15 April 2020; Accepted: 30 April 2020; Published: 30 July 2020

check for updates

\begin{abstract}
This study scrutinizes the influence of external obligation on the cost of living in Nigeria. In recent times, Nigeria has been tagged as the headquarters of world poverty due to the unaffordable cost of living that has resulted in all manner of crimes prevailing in the country. However, the role of foreign loans being contracted by the government in reducing consumption cost has become a concern, hence this investigation. This study made use of a secondary form of statistical records covering the period 2000-2018. The result of the data analysis has shown that external debt does not improve consumption cost, but rather aids the rising cost of living in Nigeria. In a nutshell, the study suggests that the government should invest a large chunk of the borrowed funds into agriculture and local manufacturing for sufficient food supply and provision of goods and services at reasonable costs. This study recommends support for infant industries and entrepreneurship to reduce the consumption cost in the country. The study also encourages the government to seek debt rearrangement or outright revocation by the lending institutions and countries.
\end{abstract}

Keywords: external debt; consumption cost; exchange rate; debt serving; finances

\section{Introduction}

External debt financing is a developmental necessity that is difficult to avoid, especially in a developing economy such as that of Nigeria. However, there is currently great concern about the disparity between foreign debt accumulation and the cost of living in the country. Many scholars have found that external debt is detrimental to a nation's economic system [1-9], largely due to its mismanagement and incorrect application. On the contrary, the findings of scholars such as [10-13] provide empirical evidence that substantiates the view that foreign obligation has a favorable effect on fiscal development. In conclusion, nations cannot afford to ignore foreign borrowing since domestic savings cannot provide sufficient funds required for the developmental projects of a nation. However, in recent times, it appears that the often-debated notion that external debt depresses an economy is finding more corroborating evidence than the view that foreign loans aid a nation's economic growth.

In Nigeria, there is a dilemma between either continuing to use external financing or discontinuing the practice, but economic and social pressure on the part of the government has kept this exercise unending; hence, the country has fallen into an economic depression caused by debt overhang. Although several studies (both local and foreign) have focused on the effects of external debt on the economic growth of a nation, the present study is concerned with the consequences of external loans 
on the cost of living in Nigeria. Let us narrow the issue at stake to its effects on consumers' cost of living, which is the cost per basket of food in the country; does it tally or is there any synchronization with the rate at which external borrowing escalates? The major goal of this study is to determine the influence of foreign liability on consumption cost, which is of the utmost importance to the average person in Nigeria. The general cost of feeding and living may be considered immaterial to the highest social class, but the ordinary Nigerian feels the pain of the exorbitant cost per basket of goods and services; thus, this study is aimed at evaluating the influence of government external borrowing on the cost of living in Nigeria.

External debt or foreign obligation alludes to the segment of a nation's general obligation that is acquired from remote loan specialists including business banks, governments and universal monetary organizations [14]. The worldwide budgetary foundations include the World Bank and the International Monetary Fund (IMF). When cash is acquired from foreign moneylenders (typically European, North American, or Japanese), a premium must be paid of an amount similar to the advance that is taken; in this way, the nation receiving the money might be required to send out its merchandise to the bank nations to gain that cash [15]. An offensive obligation disaster occurs when a powerless economy is unequipped to meet this obligation, overhauling commitments; thus, this government will fall back on tolerating socially and environmentally unfriendly conditions [16]. Business Dictionary [16] referred to debt servicing as the installment of principal and interest due on a current obligation. The IMF [17] characterized obligation administration as the installments that must be made in regard to both principal and interest for a current advance. As indicated by the authors of [18], debt management is the amount of principal and interest installments due every year on a long-term obligation. The IMF [17] highlighted the contrast between real obligation administration and booked obligation administration. As indicated by the authors of [17], genuine obligation administration is the arrangement of installments made to fulfil an obligation commitment, including head, intrigue, and any late installment charges.

Contrastingly, planned obligation administration is the arrangement of installments, including head and intrigue that must be made for the duration of the life of the obligation [17]. In simple terms, obligation administration is the measure of cash, including the premium cost and head that necessitates occasional payments from the debtor throughout the lifespan of an advance.

A different explanation is that remote obligation is the cash that the administration and associations in a nation have acquired from associations and governments in different nations [19]. Foreign obligation is the sum a nation owes to different nations either legitimately in terms of administration to regime advances or by implication because of negative parity of exchange [15]. Be that as it may, because of a lack of assets and certain relative preferences, nations rely upon each other to improve their financial development and to support monetary advancements [2]. Household reserve funds will most likely be unable to give all the necessary foundations to prompt the industrialization of an emerging nation. Consequently, developing nations depend on outer financing to fill their formative vacuity, including satisfying the monetary development requirements that their household savings cannot fulfil.

The Consumer Price Index (CPI) is the proportion of living costs dependent on changes in retail costs. It reflects changes in the expense to the normal buyer of gaining a crate of products and ventures that might be fixed or changed at determined interims, for example, yearly. The Consumer Price Index is a month to month estimation of costs in US dollar for most family unit merchandise and ventures. It reports expansion, or rising costs, and emptying, or falling costs [20]. Consumer Price Index also refers to a comprehensive measure utilized for the valuation of price changes in a container of merchandise and enterprises illustrative of utility costs in an economy [21]. In Nigeria, the Consumer Price Index or CPI estimates changes in the costs paid by buyers for a bin of merchandise and ventures. Along these lines, CPI is a portion that evaluates the weighted normal of costs of a bin of consumer products and ventures, for instance, carriage, nourishment, and therapeutic considerations. It is determined by taking significant fluctuations for everything in the foreordained bin of products and averaging them [22]. Changes in the CPI are utilized to survey value changes related to the average 
cost for basic items; the CPI is one of the most commonly used tools for recognizing times of expansion or collapse [22].

\section{Literature Review}

\subsection{Theoretical Review}

\subsubsection{Crowding-Out Effect Theory}

This work has been driven by the crowding-out effect theory, which states that the burden of liability maintenance on an administration decreases open disbursement, restricting outflow on public capital projects such as educational upgrades and hospitals, which are essential for fiscal development. This implies that when public expenditure declines, the cost of living skyrockets because government spending subsidizes the consumption cost for both industries and households. Thus, when public expenditure is decreasing, the cost of production increases and some industries are forced to cease operation where it becomes impossible to cope with the high cost of materials. Besides, profound obligation commitment means that the administration's transient income must be utilized to support the obligation, therefore crowding out open ventures into the economy [23]. The decrease in open ventures can prompt a lessening in private speculation since some private ventures and open ventures are correlative $[24,25]$. Reliance on outer advance securing is not a shrewd idea because extraordinary local acquisition brings about budgetary trickiness and crowds out private investment and entrepreneurship [26]. Yet additionally, as discussed in [27], it is important for developing countries in their underlying periods of improvement to acquire remotely since local reserve funds at that stage could be inadequate for the accomplishment of the required advancement.

\subsubsection{Dual Gap Theory}

The dual gap theory posits that advancement is subject to investment ventures, which may take place when household investment funds are insufficient to accomplish the required improvement of a country. In light of this reason, the administration of the developing country looks to secure some type of foreign credits to increase the current household reserve funds in order to have the option to satisfactorily lay down foundations and other formative ventures [3]. The dual gap hypothesis determines that there ought to be an overabundance of import over export (for example $M>E$ ). That is, Investment - Savings = Import - Export $(\mathrm{I}-\mathrm{S}=\mathrm{M}-\mathrm{E})$. In the national pay bookkeeping, an excess of speculation over household savings is equivalent to the overflow of import over a fare. Salary $=$ Consumption + Import + Savings, while Output $=$ Consumption + Export + Investment Income. This is the reason for the dual gap investigation; it demonstrates that there exists a reserve funds speculation gap when domestic savings is not at exactly the necessary level to accomplish the objective development rate. In a comparative vein, if the most extreme import prerequisite to understand the development target is bigger than the greatest conceivable degree of fare, at that point there is an export-import exchange vacuity [28]. As it were, the financing of capital tasks is anything but a domestic issue; it requires outside advances to have the option to meet the necessary money-related commitments for their development, be it for dams, street and railroad developments, medical clinics, schools, or power stations, among others [3].

\subsection{Empirical Review}

\subsubsection{Confirmatory Studies that Foreign Commitment Improves Fiscal Progress}

Abuzaid [29] utilized two conditions to investigate the effect of foreign obligation on financial development and interest in Egypt, Morocco, and Tunisia from 1982 to 2005. The examination showed that foreign obligations affected venture altogether and emphatically. Sulaiman and Azeez [30] contemplated the impact of external debt on monetary development of Nigeria utilizing the customary least-squares (OLS) method and other applicable measurable apparatuses to examine the information 
acquired from the Central Bank of Nigeria Statistical Bulletin and Debt Management Office from 1970 to 2010. The examination discovered proof that foreign obligations had decidedly added to Nigeria's financial development. Even though this discovery is opposed when contrasted with physical substances, notwithstanding, the authors suggested that external obligation ought to be procured only for financial development purposes and not for political reasons. Kasidi and Said [31] applied a common least-squares (OLS) strategy to assess the effects of foreign obligation on monetary development of Tanzania from 1990 to 2010. The outcomes indicated that stock from foreign obligations had a noteworthy positive effect on Gross Domestic product (GDP).

Shehu and Aliyu [32] assessed the commitment of outside obligation on the financial development of Nigeria utilizing the normal least-squares strategy and information covering the period from 1970 to 2010. The examination found that foreign obligation added emphatically to the financial development of Nigeria. Zaman and Arslan [33] utilized the customary least-squares relapse procedure to survey the role of foreign obligation in deciding financial development in Pakistan for an extended period. The investigation utilized GDP as an intermediary for monetary development, while financial obligation was estimated by foreign obligation stock, notwithstanding other control factors that incorporate gross local savings and gross capital arrangement. Examination relapse uncovered that foreign stock and gross capital arrangement positively affected GDP.

Mahmoud [34] utilized a customary least-squares system to explore the effect of outside obligation on the financial development of Mauritania. The investigation secured a time of 30 years, utilizing the information traversing from 1975 to 2005, which was gathered from the World Development Indicators and International Monetary Fund. The reliant variable utilized was GDP, while foreign obligation and adjustment were the informative factors. The relapse result uncovered the presence of a positive connection between GDP and foreign obligation, while a negative relationship was found between GDP and foreign overhaul. Ijirsha, Joseph, Godoo [10] applied a mix of illustrative measurements and econometric devices to investigate the connection between foreign obligation and financial development in Nigeria from 1981 to 2014. The aftereffect of the examination demonstrated that foreign obligation stock had a critical, positive effect on financial development both in short- and long-term runs. External obligation servicing contrarily and altogether affected on monetary development of Nigeria.

Monogbe [35] inspected the long-haul impact of foreign obligation on Nigeria's monetary development from 1981 to 2014 utilizing a co-reconciliation test, a Granger causality test, and standard least-squares strategy. The examination found that foreign obligation had a positive and strong association with monetary development. Ndubuisi [12] broadened the examination on the effect of foreign obligation on Nigerian monetary development from 1985 to 2015 utilizing a standard least-squares technique and some other measurable devices. The control factors utilized were the swapping scale and foreign savings, while the significant variables incorporate foreign obligation stock and foreign obligation overhaul. The examination additionally utilized GDP as the dependent variable. In this way, the discoveries uncovered that obligation to administration installment had an immaterial, negative effect on monetary development, while the foreign obligation stock had a critical, positive effect on the financial development of Nigeria. The control variable, which included outer hold and conversion scale, significantly affected GDP. Along these lines, the examination prescribed utilization of foreign obligation for infrastructural advancement.

Elwasila [36] examined the impact of foreign obligation on the financial development of Sudan from 1969 to 2015, utilizing vector mistake amendment strategy (VECM). The examination additionally utilized a conversion scale and outside direct venture as the controlling elements. The dependent variable was GDP, while the proportion of foreign obligation was the intermediary variable for foreign obligation, which is a fundamental logical variable. In this manner, the discoveries uncovered that the proportion of foreign obligation had decidedly affected Sudan's economy, while the control factors (swapping scale and Foreign Direct Investment) utilized implied a negative impact on GDP development in Sudan. Matuka and Asafo [11] inspected the effect of foreign obligation on financial 
development in Ghana utilizing a co-combination investigation and a mistake remedy approach. The examination utilized annual arrangement information covering a period from 1970 to 2017. The discoveries showed that foreign obligation decidedly affected the financial development in Ghana, both in the long and short terms. Odubuasi, Uzoka and Anichebe [13] broadened the examination on the effect of foreign obligation on the financial development of Nigeria from 1981 to 2017 utilizing Augmented Dickey-Fuller (ADF) and Granger Causality and Error Correction models. The discoveries uncovered that foreign obligation and capital use had a positive and critical impact on monetary development, while the cost of overhauling had no effect on financial development.

\subsubsection{Studies Substantiating that External Debt is Harmful to Fiscal Progression}

Ajayi and Oke [37] examined the impact of foreign obligation on financial development and advancement of Nigeria utilizing common least-squares relapse and auxiliary information over an extended period of time. The outcomes indicated that foreign obligation problems unfavorably affected the national salary and per capita pay in Nigeria. The examination further uncovered that the colossal size of Nigeria's foreign obligations prompted downgrading the country's cash, poor instructive framework, modern strikes, and development of labor conservation movements, which are just as upsetting as monetary stagnation. Rifaqat and Usman [38] surveyed the effect of foreign obligation on the monetary development of Pakistan utilizing both long- and short-term methodology for a period covering 1970-2010. The examination utilized Gross National Product as an element of foreign obligation related to other control factors, which include consumption for instruction, capital, and work power. The discoveries uncovered, among others, that foreign obligation impacted financial development, in this way affirming monetary development is blocked when problems arise in foreign obligation.

Mukui's [39] investigation attempted to respond to inquiries of whether foreign obligation and overhaul installment had noteworthy impacts on the financial development of Kenya. The investigation utilized a straight model to break down the effect of foreign obligation on the monetary development of Kenya from 1980 to 2011 while still considering control factors, for example, capital arrangement, household savings, swelling, work power, and remote direct speculation. The outcomes demonstrated that foreign obligation and obligation overhaul impact financial development. The control factors that additionally had similar negative impacts were local savings, swelling, and work power.

Ejigayehu [40] analyzed the impact of foreign obligation on the monetary development of exceptionally obligated, poor African nations through the impacts of obligation degree and crowding out. The investigation chose 8 out of 26 African nations and secured a period from 1991 to 2010. The nations examined included Mali, Ethiopia, Senegal, Benin, Madagascar, Tanzania, Uganda, and Mozambique. The aftereffects of the investigation uncovered that outside obligation unfavorably influenced financial development through the impact of crowding out.

Panizza and Presbitero [26] applied variable methodology to decide if open obligation causally affected monetary development in some selected Organization for Economic Co-activity and Development (OECD) nations. There was no causal impact found; however, the outcomes uncovered that open obligation had a prominent, negative association with financial development. Shahzad et al. [6] inspected the effect of foreign obligation on the monetary development of Pakistan utilizing information secured from 1980 to 2013. The discoveries uncovered that foreign obligation had a noteworthy, negative effect on GDP. Zouhaier and Fatma [41] examined the impact of obligation on the financial development of 19 developing nations from 1990 to 2011 utilizing the dynamic board information model. The investigation found that complete foreign obligation to GDP and foreign obligation as a level of GNI negatively affected monetary development. The discoveries, likewise, uncovered that foreign obligation negatively affected interest in the 19 nations.

AL-Refai [42] researched the effect of obligation on the financial development of Jordan from 1990 to 2013. The examination applied Cobb-Douglas generation work and the customary leastsquares technique to observationally examine the connection between obligation and financial 
development. The discoveries showed that foreign obligation and work negatively affected Jordan's monetary development. Halima [43] examined the impact of foreign open obligation on the monetary developments in Kenya, Rwanda, Tanzania, and Uganda utilizing fixed-impact and arbitrary-impact model estimation techniques and board information spanning 1981 to 2014. The outcomes uncovered that outer obligation negatively affected monetary development in the four East African Countries. The discoveries further uncovered that local obligation and macroeconomic factors, for example, expansion rate, genuine loan fee, and conversion scale, were immaterial in clarifying financial development, while capital stock emphatically affected monetary development. The investigation further deteriorated nearby monetary standards; however, harmony was proposed between remote investment and domestic advances.

Munzara [44] contemplated the impact of remote obligation on the monetary development of Zimbabwe from 1980 to 2013 utilizing conventional least-squares relapse. The control factors applied in the examination included capital venture, work power, and exchange transparency. The outcomes demonstrated that foreign obligation and exchange transparency adversely affected financial development, while capital speculation and work power positively affected Zimbabwe's monetary development. The investigation emphasized decreased dependence on remote acquisitions yet suggested a favorable domain that could directly draw in outside venture. Siddique et al. [8] utilized board information of 40 particularly poor nations from 1970 to 2007 to look at the effect of remote obligation on monetary development. The examination utilized board information estimations from an Auto-regressive Distributed Lag model. The outcomes uncovered that foreign obligations of these poor nations negatively affected monetary development both in the long and short term. Saxena and Shanker [45] inspected the connection between financial development and foreign obligation in India utilizing the customary least-squares method and auxiliary-type information from 1991 to 2015. The examination found the presence of a negative connection between the Gross Domestic Product (GDP) and India's foreign obligation stock.

Mbah et al. [46] utilized a mistake adjustment model and ARDL-bound testing to survey the effect of foreign obligation on monetary development in Nigeria from 1970 to 2013 . The examination found a historic relationship between the variables and further settled that foreign obligation had a noteworthy negative effect on the financial development of Nigeria. The investigation suggested taking judicious action and instigating trade. In the investigation of [9], GDP was an element of the foreign obligation stock, foreign obligation administration, and the control variable was the swapping scale. The examination secured a period from 1980 to 2013 and utilized a mistake revision model and normal least-squares strategy; thus, swapping scale was found positively associated with GDP while foreign obligation stock and foreign obligation administration installment had negative effects on GDP.

Afolabi, Laoye, Kolade, et al. [2] examined the long and transient relationship between foreign obligation and monetary development in Nigeria. The examination investigated the period from 1980 to 2014, and it applied a blunder remedy model and Granger causality test to experimentally test the relationship existing among the factors. In this manner, the discoveries demonstrated that foreign obligation was negatively associated with financial development in Nigeria. The proposal is that foreign obligation ought to be prudently utilized to arrange frameworks and ventures that will result in monetary improvement and development. Onakoya and Ogunade [47] utilized the OLS method to prove the ramifications of foreign obligation on Nigeria's monetary development. The examination investigated a period from 1981 to 2014, and it found that foreign obligation did not impact monetary development at the $5 \%$ level according to the Granger causality test. This discovery suggests that foreign procurement in Nigeria is not utilized for formative activities, which are the significant drivers for outside advances. Senadza, Fiagbe and Quartey [5] explored the impact of foreign obligation on financial development in 39 Sub-Saharan Africa (SSA) nations from 1990 to 2013. The examination utilized a framework of summed techniques for minute estimation strategy, and it found foreign obligation had a negative impact on the monetary development of the 39 SSA nations. 
AL-Kharusi and Mbah [48] utilized an autoregressive conveyed slack co-combination approach and a blunder amendment component to examine the short-term impact of foreign obligation on monetary development. The examination utilized information from 1990 to 2015 gathered from the World Bank and the Central Bank of Oman. The discoveries demonstrated a large, negative impact of outside obligation on the financial development of Oman. The examination further uncovered that fixed capital had a critical, positive effect on monetary development. Shkolnyk and Koilo [7] precisely inspected the connection between foreign obligation and monetary development in Ukraine from 2006 to 2016 utilizing distinctive econometric strategies. The investigation analyzed elevated levels of foreign obligation and development of an insecure macroeconomic monetary block. The investigation further uncovered that the obligation trouble of Ukraine, as found in other rising economies, had denied them anticipated monetary improvement. AL-Tamimi and Jaradat [1] researched the effect of foreign obligation on monetary development in Jordan utilizing annual information covering a period from 2010 to 2017. The experimental discovery uncovered that foreign obligation had a large, negative effect on financial development. Along these lines, the investigation recommended outside direct venture as an elective technique for financing.

\section{Research Methods}

\subsection{Investigation Strategy and Data Gathering}

This investigation utilized a causal research structure, which assesses the impact of one variable on another [49]. A causal research configuration concurs with this investigation, which tries to investigate the impact of foreign obligation on the utilization cost in Nigeria. Here, the econometric strategy embraced for examination is the normal least-squares (OLS) different relapse method because of its straightforwardness and clearness in investigation. The investigation utilized optional information spanning from 2000 to 2018. All information utilized in this examination was acquired from the Central Bank of Nigeria Statistical Bulletin, 2018 release, and the World Bank. Because of the distinction in the qualities, all information was communicated in a logarithm structure so it could be compared on a similar basis. A normality test (see Appendix D) and descriptive statistics (Appendix C) were carried out to establish that the dataset was normally distributed. A multicollinearity test was also considered necessary and can be found in Appendices A and B.

\subsection{Model Specification}

The functional and econometric association between the dependent variable (Consumer Price Index) and the explanatory variables (external debt, debt servicing, and exchange rate) can be observed in the equation below:

$$
\begin{gathered}
\text { CPI }=f(\text { EXD, DTS, XGR }) \\
\text { LOGCPI }=\beta_{0}+\beta_{1} \text { LOGEXD }+\beta_{2} \text { LOGDTS }+\beta_{3} \text { LOGXGR }+\mu
\end{gathered}
$$

Where:

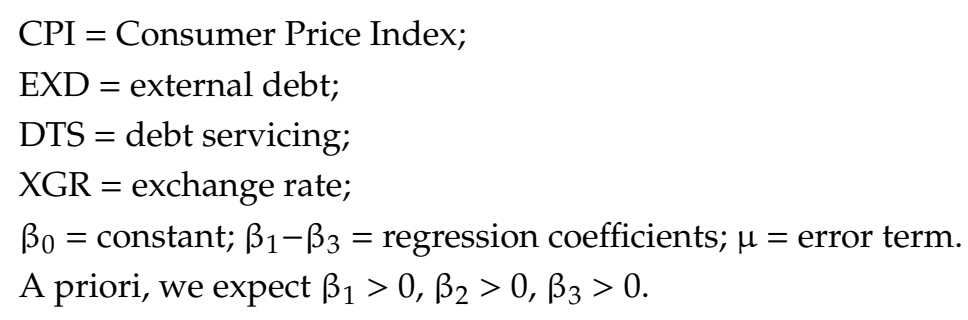

\section{Data Analysis and Interpretation}

From Table 1 above, the correlation (R) was $98.1 \%$, which signifies a strong, positive relationship between CPI and the explanatory variables. The coefficient of determination of $96.2 \%$ was equally 
very high and suggests that independent variables (XGR, EXD, and DTS) could explain about $96.2 \%$ of the variations in CPI. Only 3.8\% related to other variables outside the model. This result indicates that external debt determines the consumption cost in Nigeria to a greater extent. In other words, the higher external debt is, the higher the cost of goods and services. The standard error was employed to check the correctness of the estimates represented by the regression line measuring the exactitude of the predicted figures. When it is very small, i.e., less than 1 or 0 , it is perfect. Thus, standard error of the estimate had the value of 0.057 , which implies that the regression line and the correlation, as well as the predicted values, were accurate. The Durbin-Watson value of 1.95 , which is approximately 2 , indicates the absence of autocorrelation in the distribution.

Table 1. Model summary.

\begin{tabular}{cccccc}
\hline Model & $\mathbf{R}$ & $\mathbf{R}^{\mathbf{2}}$ & ${\text { Adjusted } \mathbf{R}^{\mathbf{2}}}$ & Std. Error of the Estimate & Durbin-Watson \\
\hline 1 & 0.981 & 0.962 & 0.955 & 0.05718721 & 1.952 \\
\hline
\end{tabular}

Predictors: (constant), exchange rate (XGR), external debt (EXD), and debt servicing (DTS); Dependent variable: Consumer Price Index (CPI); Authors' computations, 2020.

The F statistic in Table 2 above is 127.255 , while the significance value is 0.000 , which is $<0.05$ level of significance. This result was statistically significant and indicated that the model was a good fit. Thus, the independent variable jointly and significantly impacts the dependent variable (CPI).

Table 2. ANOVA.

\begin{tabular}{ccccccc}
\hline & Model & Sum of Squares & Df & Mean Square & F & Sig. \\
\hline \multirow{2}{*}{1} & Regression & 1.249 & 3 & 0.416 & 127.255 & 0.000 \\
& Residual & 0.049 & 15 & 0.003 & & \\
& Total & 1.298 & 18 & & & \\
\hline
\end{tabular}

Dependent variable: CPI; b. Predictors: (constant), XGR, EXD, DTS; Authors' calculations, 2020.

From Table 3 above, the Variance Inflation Factor (VIF) was less than 10, which is the benchmark to establish the presence or absence of multi-collinearity [50]. Thus, a VIF of less than 10 of all explanatory variables suggests that there is no multicollinearity in the set of independent variables used in this study. The t-statistics were employed to test the level of impact the independent variables had on the consumption cost proxied by CPI. It can be observed from Table 3 above that the external debt (EXD) had a significant, negative impact on CPI ( $\mathrm{t}$-statistic $=-2.658 ; p$-value $=0.018<0.05)$. This result is consistent with the findings of numerous scholars $[1,3-5,7,26,45,46]$, among others, whose studies have revealed that external debt has an overt, harmful effect on the economic progress of countries.

Table 3. Coefficients.

\begin{tabular}{|c|c|c|c|c|c|c|c|c|}
\hline & \multirow[t]{2}{*}{ Model } & \multicolumn{2}{|c|}{$\begin{array}{l}\text { Unstandardized } \\
\text { Coefficients }\end{array}$} & \multirow{2}{*}{$\begin{array}{c}\text { Standardized } \\
\text { Coefficients }\end{array}$} & \multirow[t]{2}{*}{$\mathrm{T}$} & \multirow[t]{2}{*}{ Sig. } & \multicolumn{2}{|c|}{ Collinearity Statistics } \\
\hline & & B & Std. Error & & & & Tolerance & VIF \\
\hline \multirow{4}{*}{1} & (Constant) & -0.404 & 0.739 & & -0.547 & 0.592 & & \\
\hline & EXD & -0.148 & 0.056 & -0.224 & -2.658 & 0.018 & 0.355 & 2.816 \\
\hline & DTS & 0.629 & 0.097 & 0.866 & 6.465 & 0.000 & 0.140 & 7.120 \\
\hline & XGR & 0.579 & 0.417 & 0.179 & 1.387 & 0.186 & 0.152 & 6.579 \\
\hline
\end{tabular}

Dependent variable: CPI; Authors' computations, 2020.

However, the studies of some other scholars such as $[10-13,29,30,32-34,36]$ have provided conflicting evidence. From Table 3 above, the exchange rate (XGR) had an immaterial, positive impact on CPI, while debt servicing (DTS) had a significant, positive impact on CPI. 


\section{Conclusions and Recommendation}

\subsection{Conclusions}

The major aim of this study was to determine the effect of external debt on consumption cost in Nigeria. Consumption cost is an important economic factor that suggests the amount of money citizens spend on goods and services. Most times, government efforts to minimize this cost are through foreign borrowing, which is invested into so many economic sectors to reduce consumption cost. However, the result of this study indicated that external debt, which was the major independent variable used in this study, had a significant adverse effect on the cost of living in Nigeria. Elements contributing to the high cost of living in Nigeria have been under investigation by researchers and scholars; however, this study has provided proof that reckless contraction of foreign loans has a weighty negative influence on the cost of living. This is because the purpose of contracting such loans, such as to reduce consumption cost, is not pursued from the outset.

Most times, foreign resources are misappropriated or misdirected to political ideas. This is a situation that affects the well-being of the country and hinders economic progress in all ramifications. Corruption is also another factor affecting the usage of foreign resources contracted for capital investment that will lead to a reduction in the cost of living. Thus, this empirical evidence also provides an enabling mechanism for policy makers to improve on policies that will enhance the usage of external debts, with more emphasis on consumption cost reduction, which will help to boost economic expansion. Nevertheless, the huge foreign debt of the country requires thoughtful attention, but other qualitative factors such as corruption, bad governance, and harsh business environments that affect local industries and even force many out of business also require the government to employ better corrective measures and policies to restrain these economic vices.

\subsection{Recommendation}

The issue of debt accumulation and its negative multiplier affects all facets of the economy in Nigeria and is a serious concern. It behooves the government to critically consider poorer masses and devise means of ameliorating this harsh economic condition, especially as it has to do with the cost of living. Although the poverty level in Nigeria is high, the government can intervene by using external loans purposely through government intervention programs such as skill acquisition, entrepreneurship promotions, the building of factories, and subsidization of all consumption costs. Efforts should be made by the authorities to reduce the cost of feeding by encouraging agriculture in the country and giving the farmers all the necessary financial and technological support.

This study also suggests a boost to infant industries and local manufacturers through making raw materials available in the local markets at affordable prices. Expansion of local markets is very necessary and will reduce the degree of importing goods and services, while export of local products will be promoted in the long run. Another suggestion by this study is that the government can reduce borrowing, and gradually stop, while making an effort to renegotiate with the lender countries and institutions on debt rescheduling or cancellation, whichever is workable.

This study strongly proposes the use of borrowed funds to boost agriculture and establish industries to create employment. Creation of job opportunities will improve the living standard of the citizens so every household can afford to pay for the cost of purchasing goods and services. The government will, in turn, be able to generate revenue through indirect taxes built into the cost of goods and services, which are paid for by the citizens without feeling the cost burden.

Nigeria requires funds to explore several untapped resources in the country; thus, the government will be doing the citizens a great favor by prioritizing the investment of foreign loans into untapped resources such as gold, limestone, iron ore, and bitumen, among others. Therefore, this study stresses proper usage of borrowed money because the good application of foreign loans will swiftly and invariably improve the economy and reduce consumption costs in the country. 
Author Contributions: Conceptualization, C.O.O.; Methodology, J.U.M.; Software, C.O.O.; Validation, B.I.E. and J.U.M.; Formal analysis, C.O.O.; Investigation, J.U.M.; Resources, C.O.O. and B.I.E.; Data Curation, B.I.E.; Writing-original draft preparation, C.O.O.; Writing—review and editing, C.O.O. and J.U.M.; Visualization, B.I.E.; Supervision, B.-C.E.; Project administration, B.-C.E.; Funding acquisition, B.-C.E. All authors have read and agreed to the published version of the manuscript.

Funding: This research was funded by Landmark University Centre for Research, Innovation and Development (LUCRID).

Acknowledgments: The authors acknowledge the publication grant from the Landmark University Centre for Research, Innovation and Development (LUCRID) for this paper. The authors wish to express their profound gratitude to the editors and independent reviewers of the Journal of Open Innovation: Technology, Market, and Complexity for their comments that helped to boost the quality of this paper.

Conflicts of Interest: The authors declare no conflict of interest.

\section{Appendix A}

Table A1. Collinearity diagnostics.

\begin{tabular}{cccccccc}
\hline \multirow{2}{*}{ Model } & \multirow{2}{*}{ Dimension } & \multirow{2}{*}{ Eigenvalue } & \multirow{2}{*}{ Condition Index } & \multicolumn{4}{c}{ Variance Proportions } \\
\cline { 5 - 7 } & & & & (Constant) & EXD & DTS & XGR \\
\hline \multirow{3}{*}{1} & 3.979 & 1.000 & 0.00 & 0.00 & 0.00 & 0.00 \\
& 2 & 0.012 & 18.554 & 0.00 & 0.28 & 0.06 & 0.00 \\
& 3 & 0.009 & 20.548 & 0.01 & 0.06 & 0.11 & 0.00 \\
& 4 & 0.000 & 173.291 & 0.99 & 0.66 & 0.83 & 0.99 \\
\hline
\end{tabular}

Dependent variable: CPI.

\section{Appendix B}

Table A2. Residual statistics.

\begin{tabular}{cccccc}
\hline & Minimum & Maximum & Mean & Std. Deviation & N \\
\hline Predicted Value & 1.4750259 & 2.2958882 & 1.9435530 & 0.26336665 & 19 \\
Residual & -0.08253891 & 0.11242338 & 0.00000000 & 0.05220454 & 19 \\
Std. Predicted Value & -1.779 & 1.338 & 0.000 & 1.000 & 19 \\
Std. Residual & -1.443 & 1.966 & 0.000 & 0.913 & 19 \\
\hline
\end{tabular}

Dependent Variable: CPI.

\section{Appendix C}

Table A3. Descriptive statistics.

\begin{tabular}{cccc}
\hline & Mean & Std. Deviation & N \\
\hline CPI & 1.9435530 & 0.26849079 & 19 \\
EXD & 3.2537700 & 0.40495365 & 19 \\
DTS & 2.6782890 & 0.36951207 & 19 \\
XGR & 1.9796258 & 0.08284279 & 19 \\
\hline
\end{tabular}




\section{Appendix D}

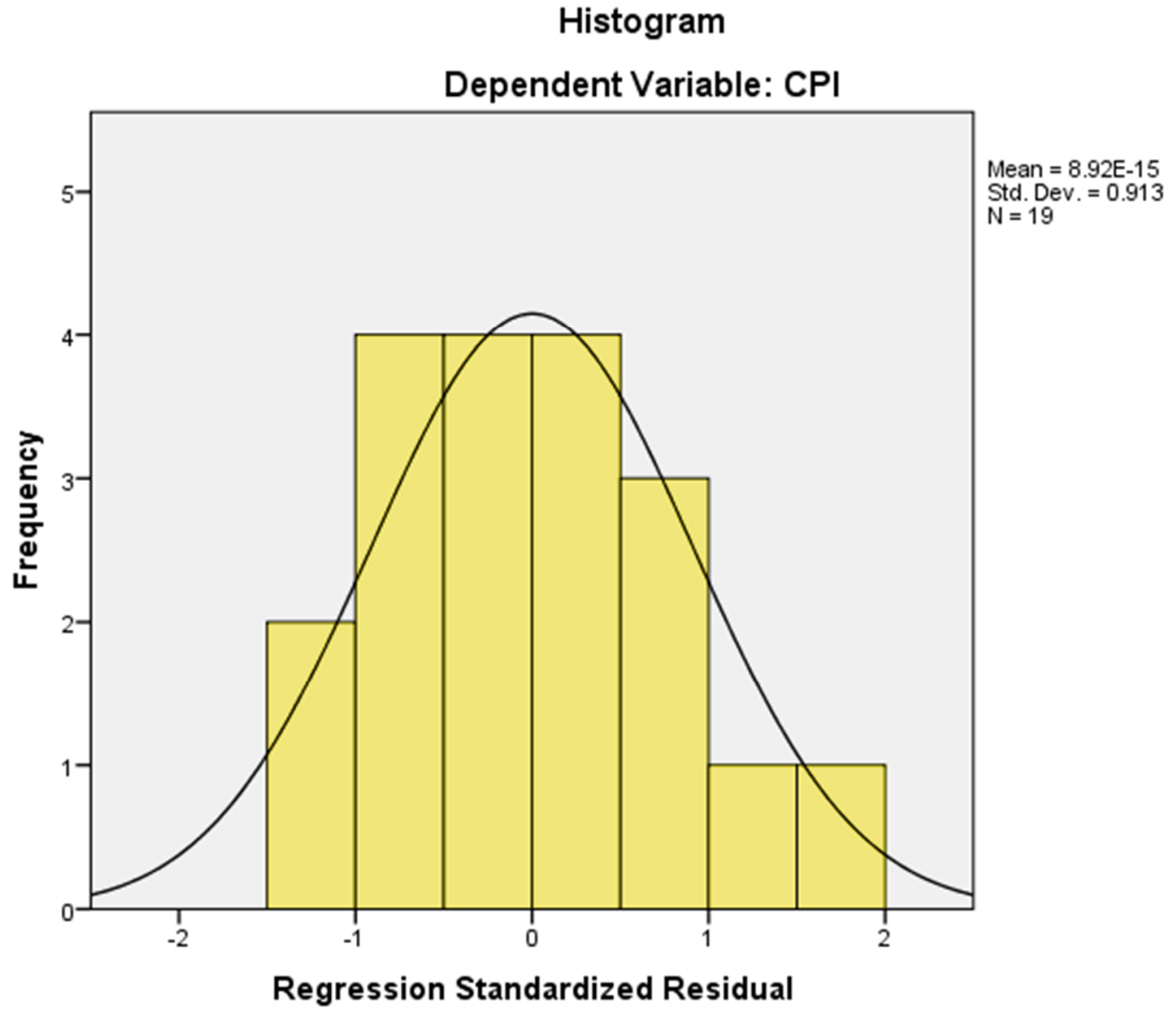

Figure A1. Normality test.

\section{References}

1. AL-Tamimi, K.A.M.; Jaradat, M.S. Impact of external debt on economic growth in Jordan for the period (2010-2017). Int. J. Econ. Financ. 2019, 11, 114-118. [CrossRef]

2. Afolabi, B.; Laoye, A.; Kolade, A.R.; Enaholo, J. The nexus between external debt and economic growth in Nigeria. Br. J. Econ. Financ. Manag. Sci. 2017, 14,1-17.

3. Omodero, C.O. External debt financing and public investment in Nigeria: A critical Evaluation. Econ. Bus. 2019, 33, 111-126. [CrossRef]

4. Omodero, C.O.; Alpheaus, O.E. The effect of foreign debt on the economic growth of Nigeria. Manag. Dyn. Knowl. Econ. 2019, 7, 291-306. [CrossRef]

5. Senadza, B.; Fiagbe, A.K.; Quartey, P. The effect of external debt on economic growth In Sub-Saharan Africa. Int. J. Bus. Econ. Sci. Appl. Res. 2017, 2, 61-69.

6. Shahzad, F.; Zia, A.; Ahmed, N.; Fareed, Z.; Zulfiqar, B. Impact of external debt on economic growth: A case study of Pakistan. Eur. Res. 2014, 89, 2133-2140.

7. Shkolnyk, I.; Koilo, V. The relationship between external debt and economic growth: Empirical evidence from Ukraine and other emerging economies. Invest. Manag. Financ. Innov. 2018, 15, 387-400. [CrossRef]

8. Siddique, A.; Selvanathan, E.A.; Selvanathan, S. The Impact of External Debt on Economic Growth: Empirical Evidence from Highly Indebted Poor Countries; Discussion Paper 15.10; The University of Western Australia: Crawley, WA, Australia, 2015.

9. Udeh, S.N.; Ugwu, J.I.; Onwuka, I.O. External debt and economic growth: The Nigeria experience. Eur. J. Account. Audit. Financ. Res. 2016, 4, 33-48. 
10. Ijirshar, V.U.; Joseph, F.; Godoo, M. The relationship between external Debt and Economic growth in Nigeria. Int. J. Econ. Manag. Sci. 2016, 6, 1-5. [CrossRef]

11. Matuka, A.; Asafo, S.S. External Debt and Economic Growth in Ghana: A Co-Integration and a Vector Error Correction Analysis; Munich Personal RePEc Archive: Munich, Germany, 2018. Available online: https: //mpra.ub.uni_muenchen.de/904631 (accessed on 13 May 2020).

12. Ndubuisi, P. Analysis of the impact of external debt on economic growth in an emerging economy: Evidence from Nigeria. Afr. Res. Rev. 2017, 11, 156-173. [CrossRef]

13. Odubuasi, A.C.; Uzoka, P.U.; Anichebe, A.S. External debt and economic growth in Nigeria. J. Account. Financ. Manag. 2018, 4, 98-108.

14. Focus Economics. External Debt (\% of GDP). Available online: https://www.focus-economics.com/economicindicator/external-debt (accessed on 9 June 2019).

15. Business Dictionary. Foreign Debt. 2019. Available online: http://www.businessdictionary.com/definition/ foreign-debt.html (accessed on 9 June 2019).

16. Business Dictionary Debt Service. 2019. Available online: http://www.businessdictionary.com/definition/ debt-service.html (accessed on 9 June 2019).

17. IMF. External Debt Statistics: Guide for Compilers and Users; Appendix 111, Glossary; IMF: Washington, DC, USA, 2003. Available online: http://www.imf.org/external/pubs/ft/eds/Eng/Guide/index.htm (accessed on 5 June 2019).

18. Merriam-Webster. Definition of Debt Service. 2019. Available online: https://www.merriam-webster.com/ dictionary/debt\%20service (accessed on 5 June 2019).

19. Cambridge Dictionary. Foreign Debt. 2019. Available online: https://dictionary.cambridge.org/ (accessed on 9 June 2019).

20. Kimberly, A. Consumer Price Index and How It Measures Inflation. 2019. Available online: https: //www.thebalance.com/consumer-price-index-cpi-index-definition-and-calculation-3305735 (accessed on 20 December 2019).

21. The Economic Times. Definition of 'Consumer Price Index'. 2019. Available online: https://economictimes. indiatimes.com/definition/consumer-price-index (accessed on 20 December 2019).

22. Chen, J. Consumer Price Index. 2019. Available online: https://www.investopedia.com/terms/c/ consumerpriceindex.asp (accessed on 20 December 2019).

23. Serieux, J.; Yiagadeesen, S. The Debt Service Burden and Growth: Evidence from Low Income Countries; The North-South Institute: Ottawa, ON, Canada. Available online: http://www.researchgate.net/publication (accessed on 13 May 2020).

24. Diaz-Alejandro, C.F. South cone stabilization plans. In Economic Stabilization in Developing Countries; Cline, W.R., Weintraub, S., Eds.; Brookings Institution: Washington, DC, USA, 1981.

25. Taylor, L. Structuralist Macroeconomics: Applicable Models for the Third World; Basic Books: New York, NY, USA, 1983.

26. Panizza, U.; Presbitero, A.F. Public debt and economic growth: Is there a causal effect? J. Macroecon. 2014, 41, 21-41. [CrossRef]

27. Todaro, P.M.; Smith, S.C. Economic Development, 9th ed.; Pearson Education: Harlow, UK; Washington, DC, USA, 2006.

28. Adedoyin, L.I.; Babalola, B.M.; Otekinri, A.O.; Adeoti, J.O. External debt and economic growth: Evidence from Nigeria. Acta Univ. Danub. Oeconomica 2016, 12, 179-194.

29. Abuzaid, L.E.M. External Debt, Economic Growth and Investment in Egypt, Morocco and Tunisia. Ph.D. Thesis, University of Gloucestershire, Gloucestershire, UK, 2011.

30. Sulaiman, L.A.; Azeez, B.A. Effect of external debt on economic growth of Nigeria. J. Econ. Sustain. Dev. 2012, 3, 71-79.

31. Kasidi, F.; Said, M. Impact of external debt on economic growth: A case study of Tanzania. Adv. Manag. Appl. Econ. 2013, 3, 59-82.

32. Shehu, U.H.; Aliyu, M. External debt and economic growth: Evidence from Nigeria. J. Econ. Sustain. Dev. 2014, 5, 1-9.

33. Zaman, R.; Arslan, M. The role of external debt on economic growth: Evidence from Pakistan economy. J. Econ. Sustain. Dev. 2014, 5, 140-147. 
34. Mahmoud, L.O.M. The role of external debt on economic growth: Evidence from Mauritania. Int. J. Econ. Manag. Sci. 2015, 4, 1-6. [CrossRef]

35. Monogbe, T.G. Intergenerational effect of external debt on performance of the Nigeria Economy. Ng-J. Soc. Dev. 2016, 5, 51-65.

36. Elwasila, S.E.M. Effect of external debt on economic growth of Sudan: Empirical analysis (1969-2015). J. Econ. Coop. Dev. 2018, 39, 39-62.

37. Ajayi, L.B.; Oke, M.O. Effect of external debt on economic growth and development of Nigeria. Int. J. Bus. Soc. Sci. 2012, 3, 297-304.

38. Rifaqat, A.; Usman, M. External debt accumulation and its impact on economic growth In Pakistan. Pak. Dev. Rev. 2012, 51, 79-96.

39. Mukui, G.K. Effect of External Public Debt on Economic Growth in Kenya. Master's Thesis, School of Economics, University of Nairobi, Nairobi, Kenya, 2013.

40. Ejigayehu, D.A. The Effect of External Debt on Economic Growth; Sodertorns Hogskola/Department of Economics, Magisteruppsats 30hp/Varterminen Soderton University: Stockholm, Sweden, 2013.

41. Zouhaier, H.; Fatma, M. Debt and economic growth. Int. J. Econ. Financ. Issues 2014, 4, 440-448.

42. AL-Refai, M.F. Debt and economic growth in developing countries: Jordan as a case Study. Int. J. Econ. Financ. 2015, 7, 134-143. [CrossRef]

43. Halima, I. Effect of External Public Debt on Economic Growth: An Empirical Analysis of East African Countries. Master's Thesis, University of Nairobi, Nairobi, Kenya, 2015.

44. Munzara, A.T. Impact of foreign debt on economic growth in Zimbabwe. IOSR J. Econ. Financ. 2015, 6, 87-91.

45. Saxena, S.P.; Shanker, I. External debt and economic growth in India. Soc. Sci. Asia 2015, 4, 15-25.

46. Mbah, S.A.; Agu, O.C.; Umunna, G. Impact of external debt on economic growth in Nigeria: An ARDL bound testing approach. J. Econ. Sustain. Dev. 2016, 7, 16-26.

47. Onakoya, A.B.; Ogunade, A.O. External debt and Nigerian economic growth Connection: Evidence from autoregressive distributed lag approach. J. Econ. Dev. Stud. 2017, 5, 66-78.

48. AL-Kharusi, S.; Mbah, S.A. External debt and economic growth: The case of emerging economy. J. Econ. Integr. 2018, 33, 1141-1157.

49. Kothari, C. Research Methodology: Methods \& Techniques, 2nd ed.; Newage International Publishers: New Delhi, India, 2004.

50. Gujarati, D.N.; Porter, D.C. Basic Econometrics, 5th ed.; McGraw-Hill Irwin: Boston, MA, USA, 2009. 